\title{
Anti-Proliferative and Apoptotic Effects of Beta-Ionone in Human Leukemia Cell Line K562
}

\author{
Zohreh Faezizadeh, ${ }^{1,}$ Amir Gharib, ${ }^{1}$ and Masoud Godarzee ${ }^{2}$ \\ ${ }^{1}$ Department of Laboratory Sciences, Borujerd Branch, Islamic Azad University, Borujerd, IR Iran \\ ${ }^{2}$ Department of Biology, Borujerd Branch, Islamic Azad University, Borujerd, IR Iran \\ "Corresponding author: Zohreh Faezizadeh, Department of Laboratory Sciences, Borujerd Branch, Islamic Azad University, Borujerd, IR Iran. E-mail: faezizadeh@gmail.com
}

Received 2015 February 20; Accepted 2015 May 5.

\begin{abstract}
Background: Beta-ionone is an aroma compound found in the Rosaceae family. Some evidence supported that beta-ionone has a great potential for cancer prevention. To date, the anti-proliferative and apoptotic effects of beta-ionone in human leukemia cell line K562 were not studied.

Objectives: Hence, we investigated whether beta-ionone could inhibit cell growth and induce apoptosis in the K562 cells.

Materials and Methods: In this experimental study, human leukemia cell line K562 was cultured and anti-proliferation effect of beta-ionone with different doses $(25-400 \mu \mathrm{m}$ ) at different times (24 - 96 hours) on treated cells was evaluated by the MTT assay. To determine apoptosis rate, the Hoechst 33342 staining and flow cytometry was performed.

Results: The MTT assay showed that beta-ionone inhibited proliferation of K562 cells in a dose-dependent manner significantly (P $=0.0008$ ). Moreover, the increased apoptotic rate was found after incubation of K562 cells with $200 \mu \mathrm{m}$ beta-ionone. The Hoechst staining and flow cytometry analysis indicated that beta-ionone could increase apoptosis of K562 cells in a dose-dependent manner. Conclusions: The results demonstrated that beta-ionone has anti-proliferative and apoptotic effects on K562 cells, and in the future may be used in the treatment of some leukemia sub-types.
\end{abstract}

Keywords: Beta-Ionone, K562 Cell Line, MTT Assay, Apoptosis

\section{Background}

The cancer is a major public health problem worldwide and approximately 10 million new cases of cancers were detected each year [1]. Cancer is a major cause of mortality in the world, mainly due to some late diagnosis and that many current treatments do not have the sufficient effectiveness [2]. Almost all the chemical anticancer agents are very toxic and have serious side effects on normal cells and therefore, the development of new anticancer drugs with high efficiencies and low toxicity is necessary $[3,4]$. It is documented that over $60 \%$ of currently used anticancer agents are derived from natural sources, including plants, marine organisms and micro-organisms [5]. In recent years, the investigation about plant-derived materials with anti-cancer activities was considered because some of these materials have low toxicity on normal cells and greater effect on cancer cells [6]. Many studies showed that some plant-derived materials could increase the apoptosis rate of cancer cells and thus could decrease the mortality and morbidity of cancers [7-9]. Beta-ionone (Figure 1) is a carotenoids found in the Rosaceae family such as Rosa bourboniana and Rosa canina [10]. Previously, it is reported that beta-ionone possess a wide variety of physio- logical and biological activities, including antioxidant, antimutagenic and antifungal activities $[11,12]$. Altogether, dietary studies revealed that this compound exhibits chemopreventive and antitumor activities $[13,14]$. Recent studies have suggested that beta-ionone may protect free-radicalinduced damage of DNA by a mechanism other than solely direct free-radical scavenging [15]. Moreover, several in vitro studies have investigated that beta-ionone cause inhibition of cellular transformation [11,14].

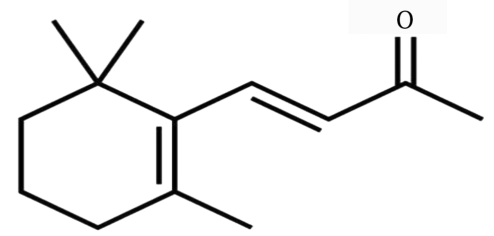

Figure 1. Chemical Structure of $\beta$-Ionone [(E)-4-(2, 6, 6-Trimethyl-1cyclohexen-1-yl)3-Buten-2-One] 


\section{Objectives}

To date, there is no report regarding the antiproliferative and apoptosis effects of beta-ionone on K562 cell line. Hence, in this study, we investigated whether beta-ionone could inhibit cell growth and induce apoptosis in $\mathrm{K} 562$ cells.

\section{Materials and Methods}

\subsection{Chemicals}

In this experimental study, fetal bovine serum (FBS), penicillin, streptomycin, RPMI-1640 and trypan blue were purchased from Gibco BRL (Gaithersburg, MD, USA). Hoechst 33342 and beta-ionone were obtained from Sigma (St Louis, MO. USA). Annexin V-PI apoptosis detection kit was purchased from Roche (Applied Science, Germany).

\subsection{Cell Culture}

Human chronic myelogenic leukemia cell line K562 was purchased from Pasteur Institute of Iran (Tehran, Iran). These cells were maintained in RPMI 1640 medium supplemented with $10 \%$ heat inactivated FBS along with penicillin (100 units $/ \mathrm{mL})$ and streptomycin $(100 \mu \mathrm{g} / \mathrm{mL})$. The cells were grown in a humidified atmosphere of $5 \%$ $\mathrm{CO}_{2}$ at $37^{\circ} \mathrm{C}$. Beta-ionone was dissolved in ethanol to obtain a $1 \mathrm{mM}$ stock solution and its subsequent dilutions were made in Roswell Park memorial institute (RPMI) medium.

\subsection{Cell Proliferation Assay}

Cell proliferation was performed using MTT assay by described method [16]. In brief, $5 \times 10^{3}$ cells were incubated in 96 well plates in the presence of different concentration of beta-ionone $(25,50,100,200,300$ and $400 \mu \mathrm{m})$ for $24,48,72$ and 96 hours in a final volume of $200 \mu \mathrm{L}$. At the end of the treatment, $20 \mu \mathrm{L}$ of MTT ( $5 \mathrm{mg} / \mathrm{mL}$ in PBS) was added to each well and incubated for an additional 2 hours at $37^{\circ} \mathrm{C}$. The purple-blue MTT formazan precipitated was dissolved in $200 \mu \mathrm{L}$ of DMSO. Subsequently, the activity of the mitochondria that reflects cellular growth and viability was evaluated by measuring the optical density at $570 \mathrm{~nm}$ on microtiter plate reader. In this experiment, the imatinib as an effective drug against K562 cells was used as positive control.

\subsection{Trypan Blue Exclusion Test}

The cultured K562 cells were treated with different concentrations of beta-ionone (25, 50,100 and $200 \mu \mathrm{m})$ for 24 , 48,72 and 96 hours. After incubation, the cultures were collected and stained with Trypan Blue at room temperature and the number of living and dead cells from the initial
100 cells both in the control and experimental groups was recorded.

Nuclear staining with Hoechst 33342: Cells were incubated with beta-ionone $(25,50,100$ and $200 \mu \mathrm{m})$ for 24 hours and subsequently were washed with PBS buffer, after fixation in freshly prepared ice-cold paraformaldehyde (0.1\%) for $10 \mathrm{~min}$, cells were stained with Hoechst 33342 $(50 \mu \mathrm{m})$ for $1 \mathrm{~min}$ in the dark condition. Morphologic changes of cells were then observed under the fluorescent microscope and the percentage of apoptotic cells was determined after counting for at least 100 cells per treatment groups.

\subsection{Flow Cytometric Analysis}

K562 cells were treated with varying concentrations of beta-ionone (25, 50, 100 and $200 \mu \mathrm{m})$ for 24 hours. At the end of each treatment, K562 cells were collected and quantitative apoptotic death assay was performed by Annexin $\mathrm{V} /$ (propidium iodide) PI staining following manufacturer's protocol, and subsequently the apoptotic cells were analyzed by flow cytometry. In this experiment, the imatinib as an effective drug against K562 cells was used as positive control.

\subsection{Statistical Analysis}

Each experiment was performed in triplicate. All data were represented as means \pm standard deviation (SD) and analysis of variance (ANOVA) was performed for all comparisons. In this study, P value $<0.05$ was accepted statistically significant.

\section{Results}

\subsection{Proliferation Study}

The effect of the beta-ionone on the growth of $\mathrm{K} 562$ leukemia cells was examined by MTT assay. The results showed that the cell proliferation was inhibited in the treated cells in a dose-dependent manner (Figure 2). The extent of inhibition increased significantly at $25 \mu \mathrm{m}$ of beta-ionone which is continued to increase up to $200 \mu \mathrm{m}$ of beta-ionone $(\mathrm{P}=0.0008)$. As shown in Figure 2 treatment with $200 \mu \mathrm{m}$ of beta-ionone had no significant effect compared to treatment with 300 and $400 \mu \mathrm{m}$ of betaionone.

\subsection{Trypan Blue staining}

The Trypan Blue staining showed that the K562 cells viabilities were inhibited in the treated cells in a dosedependent manner (Figure 3). Under identical conditions, with the extension of the culture time in the presence of beta-ionone, cell viability had decreased significantly in compared to control group. 


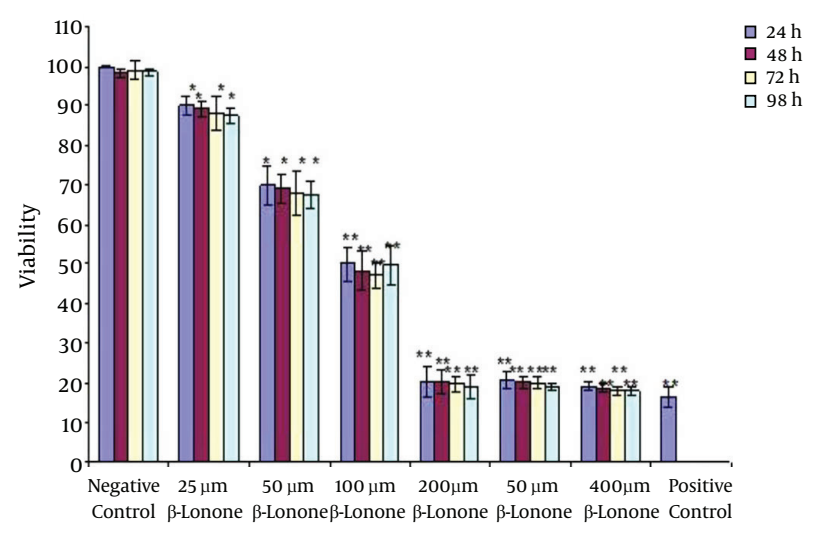

Figure 2. Dose and Time Response of K562 Cell Growth to Beta-Ionone

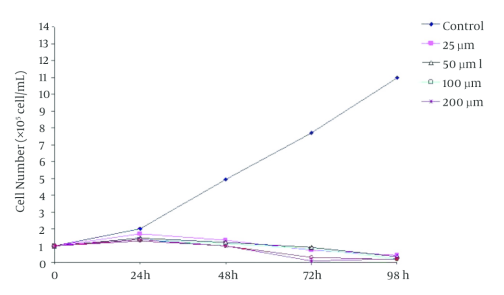

Figure 3. The Percentage of Apoptotic K562 Cells After Treatment With Beta-Ionone With Different Concentrations for Different Time Periods $\left({ }^{*} \mathrm{P}<0.05\right)$

\subsection{Hoechst 33342 Staining Study}

Further experiments were carried out to determine whether this anti-proliferative effect of beta-ionone on K562 cells viability was closely associated with apoptotic cell death. Cells treated with different concentrations of beta-ionone for 24 hours when stained with Hoechst 33342 and observed under a fluorescence microscope showed characteristic apoptotic features such as chromatin condensation and nuclear fragmentation. At least 100 cells were scored at random under a fluorescence microscope. The percentage of apoptotic cells was increased in a dosedependent manner (Figure 4).

\subsection{Flow Cytometric Study}

Beta-ionone induced apoptosis was confirmed by means of Annexin V/PI staining. As shown in the representative fluorescence-activated cell sorting (FACS) analysis scatter-grams (Figure 5), control cells showed a large viable cell population, while the treated cells with beta-ionone at $25,50,100$ and $200 \mu \mathrm{m}$ doses after 24 hours showed a shift from live cells to the apoptotic cells with a little change in necrotic cell population.

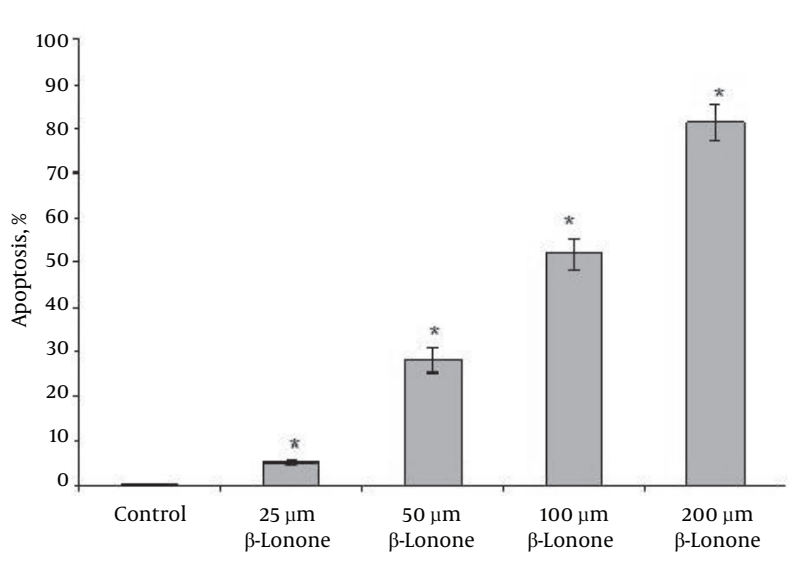

Figure 4. Hoechst Staining of K562 Cells Treated With Different Concentrations of Beta-Ionone After 24 hours

\section{Discussion}

Chemotherapy has been used for cancer treatment approximately 70 years ago by suppressing the proliferation of cancer cells. However, despite the considerable progress made with the novel chemotherapy drugs, their toxicity to normal cells and drug resistance as well as adverse side effects have remained the major obstacles for the successful clinical use. Plant-derived material possess highly diverse and complex molecular structures compared to synthetic drugs and play an important role in human health and in the development of new anticancer drugs [2-5]. Among the various classes of plant-derived compounds, carotenoids have been shown to have beneficial effects against many disorders such as cancers $[6,17]$. Carotenoids occur as hydrocarbon carotenes and oxygenated xanthophylls and were belonged to the group of plant terpenoids [9]. Previous studies have demonstrated a significant anti-cancer activity in some natural carotenoid such as lycopene [18], lovastatin [19] and butein [20]. Beta-ionone, an analogue of $\beta$-carotenoid, which is a constituent of vegetables and fruits, has been used in the experimental cancer treatment [10]. Experimental evidence for beta-ionone's benefit was strongest for anti-oxidative, anti-inflammatory and antifungal [11,14]. This carotenoid is a fragrance ingredient used in many fragrance compounds such as decorative cosmetics, fine fragrances, toilet soaps, shampoos and other toiletries, as well as in non-cosmetic products such as household detergents and cleaners [10]. Antitumor activities of beta-ionone have been demonstrated in breast cancer, melanoma and chemical-induced rat carcinogenesis [13]. In this investigation we have characterized the effect of beta-ionone on the proliferation of human leukemia cell line K562. We found that the beta-ionone significantly in- 

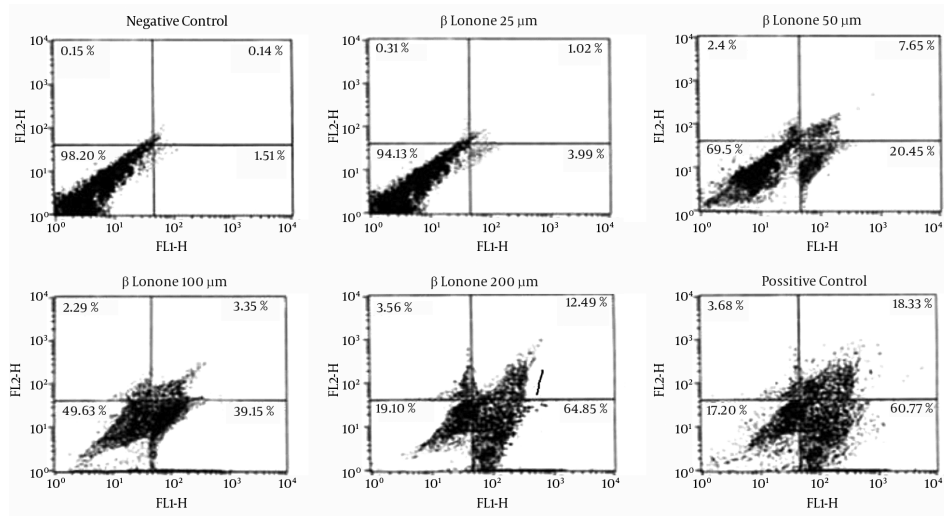

Figure 5. Flow Cytometric Analysis of K562 Cells Treated With Different Concentrations of Beta-Ionone After 24 hours

hibited proliferation of K562 cells with a dose-dependent manner. Our data are in consistent with Liu et al. that showed $\beta$-ionone has an inhibitory effect on human gastric adenocarcinoma cells growth [21]. It would be compatible with the research by Zhu et al. who have studied the effect of $\beta$-ionone on in human osteosarcoma (U2os) cells and has showed that this plant-derived compound is able to inhibit cell proliferation [22], also compatible with the research by Jones et al. that examined the effect of $\beta$ ionone in human prostate tumor cells, and showed that $\beta$ ionone inhibited cell proliferation and activates apoptosis via the mitochondrial pathway [23]. In this case, similar observations have been reported in the previous studies with other natural plant products such as lycopene [24, 25], silymarin [26], curcumin [27], epigallocatechin-3-gallate [28], celastrol [29], tea polyphenol [30], berberine [31], gossypol [32], wogonin [33], Korean red ginseng extract [34] and Curcuma longa extract [35] in various cancer cell lines. Therefore, beta-ionone and other effective plant-derived materials could be considered as the promising strategy for developing the anticancer drugs. Our results demonstrated that beta-ionone might be a good candidate for inhibiting proliferation activity in leukemia. This is the first report regarding growth inhibition of K562 cells by beta-ionone but additional studies need to establish the efficacy of betaionone in leukemia cells from patients and animal models of leukemia, which might be useful in supporting a rationale for clinical trial in leukemia patients.

\section{Acknowledgments}

This study was supported Islamic Azad University, Borujerd Branch, Iran. The authors would like to acknowledge staffs of the university. The grant of this project (code 6822) was taken by Faezizadeh.

\section{Footnotes}

Authors' Contribution: All authors had equal role in design, work, statistical analysis and manuscript writing.

Funding/Support: Borujerd Branch, Islamic Azad University, Borujerd, Iran.

\section{References}

1. Phillipson JD. Phytochemistry and medicinal plants. Phytochemistry. 2001;56(3):237-43.

2. Gonzales GF, Valerio LJ. Medicinal plants from Peru: a review of plants as potential agents against cancer. Anticancer Agents Med Chem. 2006;6(5):429-44. [PubMed: 17017852].

3. Sak K. Chemotherapy and dietary phytochemical agents. Chemotherapy research and practice. 2012;2012.

4. Igney FH, Krammer PH. Death and anti-death: tumour resistance to apoptosis. Nat Rev Cancer. 2002;2(4):277-88. doi: 10.1038/nrc776. [PubMed: 12001989].

5. Riboli E, Norat T. Epidemiologic evidence of the protective effect of fruit and vegetables on cancer risk. Am J Clin Nutr. 2003;78(3 Suppl):559S-69S. [PubMed: 12936950].

6. He L, Mo H, Hadisusilo S, Qureshi AA, Elson CE. Isoprenoids suppress the growth of murine B16 melanomas in vitro and in vivo. $J$ Nutr. 1997;127(5):668-74. [PubMed: 9164984].

7. Riebeling C, Forsea AM, Raisova M, Orfanos CE, Geilen CC. The bisphosphonate pamidronate induces apoptosis in human melanoma cells in vitro. Br J Cancer. 2002;87(3):366-71. doi: 10.1038/sj.bjc.6600476. [PubMed: 12177810].

8. Agarwal R, Agarwal C, Ichikawa H, Singh RP, Aggarwal BB. Anticancer potential of silymarin: from bench to bed side. Anticancer Res. 2006;26(6B):4457-98. [PubMed: 17201169].

9. Rao AV, Rao LG. Carotenoids and human health. Pharmacol Res. 2007;55(3):207-16.

10. Lalko J, Lapczynski A, McGinty D, Bhatia S, Letizia CS, Api AM. Fragrance material review on dihydro-beta-ionone. Food Chem Toxicol. 2007;45 Suppl 1:S225-8. doi: 10.1016/j.fct.2007.09.060. [PubMed: 18031899].

11. Gomes-Carneiro MR, Dias DM, Paumgartten FJ. Study on the mutagenicity and antimutagenicity of beta-ionone in the Salmonella/microsome assay. Food Chem Toxicol. 2006;44(4):522-7. doi: 10.1016/j.fct.2005.08.026. [PubMed: 16223554]. 
12. Janakiram NB, Cooma I, Mohammed A, Steele VE, Rao CV. Beta-ionone inhibits colonic aberrant crypt foci formation in rats, suppresses cell growth, and induces retinoid $\mathrm{X}$ receptor-alpha in human colon cancer cells. Mol Cancer Ther. 2008;7(1):181-90. doi: 10.1158/1535-7163.MCT07-0529. [PubMed: 18202021].

13. Liu JR, Dong HW, Sun XR, Wang Q, Sun WG, Parry JW, et al. Effects of beta-ionone on mammary carcinogenesis and antioxidant status in rats treated with DMBA. Nutr Cancer. 2010;62(1):58-65. doi 10.1080/01635580903191510. [PubMed: 20043260].

14. Kim MO, Moon DO, Kang CH, Kwon TK, Choi YH, Kim GY. beta-Ionone enhances TRAIL-induced apoptosis in hepatocellular carcinoma cells through Sp1-dependent upregulation of DR5 and downregulation of NF-kappaB activity. Mol Cancer Ther. 2010;9(4):833-43. doi:10.1158/1535 7163.MCT-09-0610. [PubMed: 20354117].

15. Asokkumar S, Naveenkumar C, Raghunandhakumar S, Kamaraj S, Anandakumar P, Jagan S, et al. Antiproliferative and antioxidant potential of beta-ionone against benzo(a)pyrene-induced lung carcinogenesis in Swiss albino mice. Mol Cell Biochem. 2012;363(1-2):335-45 doi: 10.1007/s11010-011-1186-6. [PubMed: 22187222].

16. Mosmann T. Rapid colorimetric assay for cellular growth and survival: application to proliferation and cytotoxicity assays. J Immunol Methods. 1983;65(1-2):55-63. [PubMed: 6606682].

17. Michaud DS, Pietinen P, Taylor PR, Virtanen M, Virtamo J, Albanes D. Intakes of fruits and vegetables, carotenoids and vitamins A, E, C in relation to the risk of bladder cancer in the ATBC cohort study. Br J Cancer. 2002;87(9):960-5. doi: 10.1038/sj.bjc.6600604. [PubMed: 12434284]

18. Gharib A, Faezizadeh Z. In vitro anti-telomerase activity of novel lycopene-loaded nanospheres in the human leukemia cell line K562. Pharmacogn Mag. 2014;10(Suppl 1):S157-63. doi: 10.4103/09731296.127368. [PubMed: 24914298].

19. Johnson MD, Woodard A, Okediji EJ, Toms SA, Allen GS. Lovastatin is a potent inhibitor of meningioma cell proliferation: evidence for inhibition of a mitogen associated protein kinase. J Neurooncol. 2002;56(2):133-42. [PubMed: 11995814].

20. Moon DO, Kim MO, Lee JD, Choi YH, Kim GY. Butein suppresses cMyc-dependent transcription and Akt-dependent phosphorylation of hTERT in human leukemia cells. Cancer Lett. 2009;286(2):172-9. doi: 10.1016/j.canlet.2009.05.028. [PubMed:19560862].

21. Liu JR, Chen BQ, Yang BF, Dong HW, Sun CH, Wang Q, et al. Apoptosis of human gastric adenocarcinoma cells induced by beta-ionone. World J Gastroenterol. 2004;10(3):348-51. [PubMed: 14760755].

22. Zhu J, Zhang L, Jin X, Han X, Sun C, Yan J. beta-Ionone-induced apoptosis in human osteosarcoma (U2os) cells occurs via a p53dependent signaling pathway. Mol Biol Rep. 2010;37(6):2653-63. doi: 10.1007/s11033-009-9793-y. [PubMed: 19757179].

23. Jones S, Fernandes NV, Yeganehjoo H, Katuru R, Qu H, Yu Z, et al. beta-ionone induces cell cycle arrest and apoptosis in human prostate tumor cells. Nutr Cancer. 2013;65(4):600-10. doi: 10.1080/01635581.2013.776091. [PubMed: 23659452]
24. Giovannucci E, Rimm EB, Liu Y, Stampfer MJ, Willett WC. A prospective study of tomato products, lycopene, and prostate cancer risk. J Natl Cancer Inst. 2002;94(5):391-8. [PubMed: 11880478].

25. Nahum A, Hirsch K, Danilenko M, Watts CK, Prall OW, Levy J, et al. Lycopene inhibition of cell cycle progression in breast and endometrial cancer cells is associated with reduction in cyclin D levels and retention of p27(Kip1) in the cyclin E-cdk2 complexes. Oncogene. 2001;20(26):3428-36. doi:10.1038/sj.onc.1204452. [PubMed: 11423993].

26. Faezizadeh Z, Mesbah-Namin SA, Allameh A. The effect of silymarin on telomerase activity in the human leukemia cell line K562. Planta Med. 2012;78(9):899-902. doi: 10.1055/s-0031-1298464. [PubMed: 22532022].

27. Gopal PK, Paul M, Paul S. Curcumin induces caspase mediated apoptosis in JURKAT cells by disrupting the redox balance. Asian Pac J Cancer Prev. 2014;15(1):93-100. [PubMed: 24528086].

28. Wang X, Hao MW, Dong K, Lin F, Ren JH, Zhang HZ. Apoptosis induction effects of EGCG in laryngeal squamous cell carcinoma cells through telomerase repression. Arch Pharm Res. 2009;32(9):1263-9. doi: 10.1007/s12272-009-1912-8. [PubMed: 19784583].

29. Ma J, Han LZ, Liang H, Mi C, Shi H, Lee JJ, et al. Celastrol inhibits the HIF-1alpha pathway by inhibition of mTOR/p70S6K/eIF4E and ERK1/2 phosphorylation in human hepatoma cells. Oncol Rep. 2014;32(1):23542. doi: 10.3892/or.2014.3211. [PubMed: 24859482].

30. Lin SC, Li WC, Shih JW, Hong KF, Pan YR, Lin JJ. The tea polyphenols EGCG and EGC repress mRNA expression of human telomerase reverse transcriptase (hTERT) in carcinoma cells. Cancer Lett. 2006;236(1):80-8. doi: 10.1016/j.canlet.2005.05.003. [PubMed: 15975707].

31. Barzegar E, Fouladdel S, Movahhed TK, Atashpour S, Ghahremani MH, Ostad SN, et al. Effects of berberine on proliferation, cell cycle distribution and apoptosis of human breast cancer T47D and MCF7 cell lines. Iran J Basic Med Sci. 2015;18(4):334-42. [PubMed: 26019795].

32. Moon DO, Kim MO, Choi YH, Lee HG, Kim ND, Kim GY. Gossypol suppresses telomerase activity in human leukemia cells via regulating hTERT. FEBS Lett. 2008;582(23-24):3367-73. doi: 10.1016/j.febslet.2008.08.029. [PubMed:18775705].

33. Huang ST, Wang CY, Yang RC, Chu CJ, Wu HT, Pang JH. Wogonin, an active compound in Scutellaria baicalensis, induces apoptosis and reduces telomerase activity in the HL-60 leukemia cells. Phytomedicine. 2010;17(1):47-54. doi: 10.1016/j.phymed.2009.06.005. [PubMed: 19577445].

34. Park SE, Park C, Kim SH, Hossain MA, Kim MY, Chung HY, et al. Korean red ginseng extract induces apoptosis and decreases telomerase activity in human leukemia cells. J Ethnopharmacol. 2009;121(2):304-12. doi: 10.1016/j.jep.2008.10.038. [PubMed: 19041934].

35. Ranjbari J, Alibakhshi A, Arezumand R, Pourhassan-Moghaddam M, Rahmati M, Zargham N, et al. Effects of curcuma Longa extract on telomerase activity in lung and breast cancer cells. Zahedan J Res Med Sci. 2014;16(10):1-6. 